\title{
The outbreak of COVID-19 in Mulhouse
}

\author{
Hospital crisis management and deployment of military hospital during the outbreak of \\ COVID-19 in Mulhouse, France
}

Khaldoun Kuteifan ${ }^{1 *}$, Pierre Pasquier ${ }^{2,3,4}$, Christian Meyer ${ }^{5}$, Jacques Escarment ${ }^{3,4}$ and Odile Theissen ${ }^{6}$

The outbreak of a novel coronavirus in Wuhan, the capital city of Hubei, China, in December 2019 raised a worldwide concern. Cases of pneumonia of unknown origin were first described and the pathogen responsible was later identified as being a novel betacoronavirus [1]. Named as the Severe Acute Respiratory Syndrome coronavirus-2 (SARS-CoV-2), this virus is responsible of the coronavirus disease 2019 (COVID-19) [2]. The outbreak began in the east of France during the first days of March after a religious meeting gathering about 2000 people, which took place in Mulhouse from 17th to 24th February 2020.

The Groupe Hospitalier de la Region de Mulhouse Sud-Alsace (GHRMSA) is a hospital complex including 10 sites with a total capacity of 2612 beds and covering the needs of 480,000 people. Intensive care facilities are located on the main site, Emile Muller Hospital, with a capacity of 824 general beds and 2 ICUs, one medical of 20 beds and one surgical of 16 beds. The first patient presenting with respiratory failure was admitted to medical ICU on March 2nd, 2020. After 4 days, 10 patients with COVID-19 were admitted. Non-COVID-19 patients were transferred from medical to surgical ICU in the first week in order to increase ICU surge capacity for COVID19 patients. In the beginning of the second week, all medical ICU beds were occupied by COVID-19 patients. The cardiac surgery ICU (4 beds) was transformed to a COVID-19 ICU, as scheduled surgical and medical activity was stopped. Sixteen additional beds were added in five operative and post-operative rooms. Eight beds

\footnotetext{
*Correspondence: kuteifank@ghrmsa.fr

1 Service de Réanimation Médicale GHRMSA, Hôpital Emile Muller, Mulhouse, France

Full list of author information is available at the end of the article
}

"non-COVID-19" ICU was created in another postoperative room. Surgical ICU was also converted into COVID-19 ICU.

On week 3 of the outbreak, in an unprecedented manner in France, a 30-bed field military intensive care hospital was deployed on the hospital car park by the French military medical service: the Élément Militaire de Réanimation du Service de Santé des Armées (EMRSSA).

So as to cope with this massive flood, a national as well as an international cooperation was setup and many patients were transferred to receptive ICUs outside the region via Alsace Regional Health Agency coordinating office, assessed by a military coordinating office, by helicopter, trains and military aircrafts in France, Germany, Luxembourg and Switzerland.

From March 2nd to April 26th, 2020, 1249 COVID-19 patients were admitted to the hospital. Among them, 278 were hospitalized in ICU. Forty-four patients were discharged from ICU, 118 were transferred to another ICU, and 42 are died. The field military intensive care hospital admitted 47 patients during the same period.

Surges in the number of critically ill patients with COVID-19 had occurred rapidly. Thus, ICU practitioners and hospital administrators had to adapt the capacity of ICU beds in number, and also in equipment, consumables, pharmaceuticals, and staffing. The staff was composed of intensivists and anesthesiologist-intensivists with one intensivist in charge of patients' orientation every day. Nursing team was composed of ICU nurses and nurse anesthetists.

The EMRSSA mission aimed to achieve two main objectives under strenuous conditions: first to treat critically ill patients with COVID-19-associated acute respiratory distress syndrome (ARDS) according to the best 
standards of care; and second, to protect the caregivers. In the first 3 weeks, more than 40 critically ill patients with COVID-19 were transferred into the EMRSSA field hospital. All of them presented under ARDS conditions and required initial protective mechanical ventilation. Each ICU wing was staffed by one anesthesiologist-intensivist, three nurses (including one certified registered nurse anesthetist), and three assistant nurses, coming from the eight military training hospitals, following European recommendations on structural and organizational requirements for ICUs [3].

The protection of the EMRSSA personnel was one of the two main objectives of the mission. As a consequence, with the help of an infection control team, who experienced Ebola crisis management in Guinea in 2015, the EMRSSA was separated into three different zones according to three different protection levels: a green zone (wearing of surgical mask); an orange zone (wearing of FFP2 mask): and a red zone (wearing of full personal protective equipment: FFP2 or FFP3 mask, gown, gloves, eye protection, and apron) [4].

Most countries cannot match China's feat of rapidly building new hospitals and ICUs during the COVID19 outbreak in Wuhan [5]. The government decision to deploy the military hospital was more adapted to our reality. Its contribution was crucial in the face of a challenge that progressed with each day. Mulhouse hospital ICU staff and military hospital staff worked together to handle the outbreak.

\section{Acknowledgements}

Not applied.

\section{Authors' contributions}

All authors were responsible for the concept of this manuscript. All authors read and approved the final manuscript.

\section{Funding}

Not applied.
Ethics approval and consent to participate Not applied.

\section{Consent for publication}

All authors have confirmed the manuscript and approved the publication of the manuscript. The corresponding author has completed the "Consent for publication".

\section{Competing interests}

The authors have no competing of interest nor any financial interest in any product mentioned in this paper.

\section{Author details \\ ${ }^{1}$ Service de Réanimation Médicale GHRMSA, Hôpital Emile Muller, Mulhouse, France. ${ }^{2}$ Département d'anesthésie-réanimation, Hôpital d'instruction des armées, Clamart, France. ${ }^{3}$ Ecole du Val-de-Grâce, Paris, France. ${ }^{4}$ Elé- ment Militaire de Réanimation du Service de Santé des Armées, Mulhouse, France. ${ }^{5}$ Service de Réanimation Chirurgicale, GHRMSA, Hôpital Emile Muller, Mulhouse, France. ${ }^{6}$ Service d'Anesthésie, GHRMSA, Hôpital Emile Muller, Mulhouse, France.}

Received: 2 May 2020 Accepted: 8 May 2020

Published online: 19 May 2020

References

1. Zhu N, Zhang D, Wang W, Li X, Yang B, Song J, et al. A novel coronavirus from patients with Pneumonia in China, 2019. N Engl J Med. 2020;382(8):727-33.

2. Rothan HA, Byrareddy SN. The epidemiology and pathogenesis of coronavirus disease (COVID-19) outbreak. J Autoimmun. 2020;109:102433.

3. Valentin A, Ferdinande P, ESICM Working Group on Quality Improvement. Recommendations on basic requirements for intensive care units: structural and organizational aspects. Intensive Care Med. 2011;37(10):157587. https://doi.org/10.1007/s00134-011-2300-7 (Epub 2011 Sep 15).

4. Berger F, Bédubourg G, Facon A, Boyavalle S, Michel H, Velut G, Duron S. Force health protection during the Ebola crisis: French experience in Guinea. J R Army Med Corps. 2017;163(3):223. https://doi.org/10.1136/ jramc-2016-000749 (Epub 2017 Feb 17. No abstract available).

5. Yang $X, Y u Y, X u$ J, et al. Clinical course and outcomes of critically ill patients with SARS-CoV-2 pneumonia in Wuhan, China: a single-centered, retrospective, observational study. Lancet Respir Med. 2020. https //doi.org/10.1016/S2213-2600(20)30079-5 (published online Feb 24).

\section{Publisher's Note}

Springer Nature remains neutral with regard to jurisdictional claims in published maps and institutional affiliations.

\section{Availability of data and materials}

Not applied.

\section{Submit your manuscript to a SpringerOpen ${ }^{\circ}$ journal and benefit from:}

- Convenient online submission

$\checkmark$ Rigorous peer review

- Open access: articles freely available online

- High visibility within the field

- Retaining the copyright to your article

Submit your next manuscript at springeropen.com 